\title{
Physical and metabolic alterations in "Prata Anã" banana induced by mechanical damage at room temperature
}

\author{
Victor Martins Maia ${ }^{1 *}$; Luiz Carlos Chamhum Salomão²; Dalmo Lopes Siqueira²; Rolf \\ Puschman²; Virgílio Jamir Gonçalves Mota Filho'; Paulo Roberto Cecon² \\ ${ }^{1}$ Unimontes - Depto. de Ciências Agrárias - Rua Reinaldo Viana, 2630 - 39440-000 - Janaúba, MG - Brasil. \\ ${ }^{2} U F V$ - Depto. de Fitotecnia - 36570-000 - Viçosa, MG - Brasil. \\ *Corresponding author < victor.maia@unimontes.br>
}

\begin{abstract}
Bananas respond at the physical and physiological level to mechanical damage. Mechanical injuries cause alterations in color and flavor, tissue softening, faster ripening, increased weight loss, increased invasion of microorganisms, and higher enzyme activity in the affected area. The purpose of this study was to verify the physical and metabolic alterations in 'Prata Anã' bananas induced by mechanical stress at room temperature. The experiment was conducted in a completely randomized, split-plot in time design, consisting of one control and four mechanical injury types: cutting, abrasion, impact and compression, sampled over time. The percentage of accumulated and daily fresh weight loss, electrolyte leakage from the injured peel region, total soluble sugar and starch contents and enzyme activity of polyphenoloxidase and peroxidase were measured. The damage caused by cutting and abrasion resulted in the highest percentage of fresh weight loss. All types of mechanical damage increased electrolyte leakage during the evaluation period, in comparison with the control. The impact damage anticipated the ripening, besides affecting the conversion of starch into total soluble sugars in the pulp. By impact and abrasion injuries, the polyphenoloxidase and peroxidase activity in the peel was increased by up to $231 \%$ and $90 \%$, and $618 \%$ and $956 \%$, respectively, compared to the control.

Key words: postharvest, musa spp., injury
\end{abstract}

\section{Alterações físicas e metabólicas em banana 'Prata Anã' induzidas por dano mecânico mantidas sob temperatura ambiente}

\begin{abstract}
RESUMO: Bananas apresentam respostas físicas e fisiológicas ao dano mecânico. As injúrias mecânicas causam alterações na cor e sabor, amaciamento dos tecidos, amadurecimento mais rápido, aumento na perda de peso, aumento no ataque e invasão de microorganismos e maior atividade enzimática na área afetada. Verificaramse alterações físicas e metabólicas induzidas por estresse mecânico em bananas 'Prata Anã' mantidas em temperatura ambiente. Foi utilizado o esquema em parcelas subdivididas no tempo, constituído de testemunha e quatro fontes de dano mecânico: corte, abrasão, impacto e compressão, com amostragens ao longo do tempo, no delineamento inteiramente casualizado. As porcentagens de perda de massa fresca acumulada e diária, o extravasamento de eletrólitos da região danificada da casca, os teores de açúcares solúveis totais e amido e a atividade das enzimas polifenoloxidase e peroxidase foram avaliadas. Os danos por corte e abrasão promoveram maior porcentagem de perda de massa fresca. Todos os tipos de dano mecânico aumentaram extravasamento de eletrólitos em relação à testemunha ao longo do período de avaliação. $\mathrm{O}$ dano por impacto antecipou o amadurecimento, além de prejudicar a conversão de amido em açúcares solúveis totais na polpa. As injúrias por impacto e abrasão aumentaram a atividade das enzimas polifenoloxidase e peroxidase na casca em até 231 e $90 \%$, e 618 e $957 \%$, respectivamente, em relação ao controle.
\end{abstract}

Palavras-chave: pós-colheita, musa spp., injúria

\section{Introduction}

Bananas respond at the physical and physiological level to mechanical damage. Physical responses are mainly linked to the appearance, with the surge of symptoms of advanced lignification and necrosis in the damaged region (Lladó and Dominguez, 1998). Due to the physiological responses, mechanical injuries cause alterations in color and flavor, tissue softening, faster ripening; these are mainly due to the increase in respiration and ethylene production, increased weight loss, increased invasion of microorganisms (Dadzie and Orchard, 1997; Lladó and Dominguez, 1998; Zeebroeck et al., 2007; Fischer et al., 2009), and higher enzyme activity in the affected area (Lladó and Dominguez, 1998).

Ferris et al. $(1993 ; 1995)$ studied plantain genotypes and environmental conditions, and observed that abrasion damage reduced the ripening period and increased the loss rate of fresh fruit weight. They also found that impact damage reduced the ripening period of fruit harvested 85 days after flowering. Cutting also caused a reduction of the ripening period without influencing the weight loss, compared with the control fruits. However, compression damage had no effect on the characteristics evaluated, compared to undamaged fruits. Compression injuries can lead to the breaking of epidermis cells, 
triggering enzymatic reactions and, consequently, the darkening of areas around the affected location, due to leakage and exposure of the cell liquid to enzyme action, inducing oxidation of phenolic compounds to quinones (Radi et al., 1997).

Mechanical damage can occur at any point in the supply chain of 'Prata Anã' banana (Maia et al., 2007), due to the technology used at harvest and post harvest. Areas with a low technical degree are prone to high rates of fruit damage and consequently, high values of postharvest losses. In such areas, workers are usually untrained and unqualified, the fruits are harvested and dumped on the ground, there is no protection for the transport in the plantation, wooden boxes or other heavy packaging material above the recommended weight is used for packaging. Furthermore, fruits are transported on roads without maintenance and on open trucks, and handling during ripening and storage, distribution and retail sale are inappropriate.

There are few studies on the effects of mechanical damage on 'Prata Anã' banana. The purpose of this study was to verify the physical and metabolic changes induced by mechanical stress in 'Prata Anã' banana at room temperature.

\section{Material and Methods}

The experiment was conducted with a "Prata Anã" banana $(\mathrm{AAB})$ from a commercial orchard located in Verdelândia, state of Minas Gerais, Brazil (15²4' S; $43^{\circ} 43^{\prime} \mathrm{W} ; 480 \mathrm{~m}$ asl, climate classification Aw, according to Köppen). A split-plot in time analysis was used, where the treatments consisted of: T1 - control without mechanical damage and four types of mechanical damage: T2 - cutting, T3 - abrasion, T4 - impact, and T5 pressure or compression. Samples were collected within a period of nine days, based on a completely randomized design with three replications and three fruits per plot.

The bunches were collected in November 2003 when the central fruits of the second hand had reached a diameter of $36 \pm 2 \mathrm{~mm}$. After harvesting the second bunch, a third and fourth hand of each one were also removed, washed, identified, wrapped in bubble plastic and packed in corrugated boxes. The boxes were labeled by a cut close to the flower cushion and washed in a $0.2 \%$ detergent solution for five minutes. Thereafter, the fruits were padded in plastic boxes lined with shredded paper and stored for nine days at room temperature (mean of $25.4 \pm 1.9^{\circ} \mathrm{C}$ and $82 \pm 9.1 \%$ relative humidity), until and after the treatments.

Fruits with a completely green peel, in other words, rated as peel color 1 (Dadzie and Orchard, 1997), were damaged by impact, pressure or compression, abrasion, and cutting. The fruits were damaged, one by one, in the central region, between two nooks, on two areas of $10 \mathrm{~cm}^{2}$ each $(2 \mathrm{~cm}$ by $5 \mathrm{~cm})$, totaling $20 \mathrm{~cm}^{2}$.

Cutting was performed with a stylus in three $5 \mathrm{~cm}$ long cuts, spaced $1 \mathrm{~cm}$ apart, to a depth of $2 \mathrm{~mm}$. Other fruits were abraded by rubbing sand paper $\mathrm{N}^{\circ} 80$ over the previously delimited area. Fruits were impact-damaged according to a methodology described by Dadzie and Orchard (1997), by letting a steel ball (66 g) drop on the fruits from a height of 1.5 meters. The impact energy was $0.9712 \mathrm{~J}$. The fruits were damaged by compression by maintaining a weight of $3 \mathrm{~kg}$ for 5 minutes on the fruits.

The following characteristics were evaluated: loss percentage of fresh weight; the loss rate of fresh fruit weight, i.e., the daily loss percentage of fresh weight; electrolyte leakage from the damaged peel region; contents of total soluble sugars and starch; and enzyme activity of polyphenoloxidase and peroxidase. The cumulative percentage of fresh weight loss and daily rate of fresh weight loss were determined daily in duplicate samples, consisting of three fruits each. The electrolyte leakage, total soluble sugar and starch contents and enzyme activity of polyphenoloxidase (PPO) and peroxidase (POD) were determined every two days. For this purpose, the fruits were sampled randomly during ripening. The fruits were weighed together to determine the daily reduction of fresh weight assessed as described by Dadzie and Orchard (1997).

The electrolyte leakage was determined using the methodology described by Whilton et al. (1992), by which a piece (diameter $1 \mathrm{~cm}$ ) of damaged peel per fruit is removed. This section was washed in distilled water and surface-dried on absorbent paper, and then incubated for 2 hours in a test tube with lid, containing $18 \mathrm{~mL}$ of distilled water and maintained at room conditions. After this period, the electrical conductivity was measured with a conductivity meter (Schott, model CG 853). Subsequently, the tubes containing the peel samples were autoclaved at $121^{\circ} \mathrm{C}$ and $1.5 \mathrm{~atm}$ for $30 \mathrm{~min}$ and the reading of the electrical conductivity was repeated. Results were expressed as the ratio of the values of the first by the second measurement, multiplied by 100 .

Subsamples were taken from the bruised region, approximately $500 \mathrm{mg}$ pulp for the determination of starch and sugar contents, and 1,000 $\mathrm{mg}$ peel to determine the PPO and POD activity. These samples were deep-frozen in liquid nitrogen $\left(-196^{\circ} \mathrm{C}\right)$ and stored at $-20^{\circ} \mathrm{C}$ until the evaluations.

To determine the sugar and starch contents, the samples were homogenized in a polytron with $80 \%$ ethanol and centrifuged at 2,000 $\mathrm{x} g$ for $10 \mathrm{~min}$. The precipitate was extracted again and centrifuged for three more times, and the supernatants were combined and the volume completed to $25 \mathrm{~mL}$. Ten milliliters of the supernatants together were completely evaporated in a vacuum rotary evaporator, at approximately $45^{\circ} \mathrm{C}$, and the residue resuspended in $5 \mathrm{~mL}$ of distilled water, and stored at $-20^{\circ} \mathrm{C}$ until analysis. From this extract, aliquots were taken to determine the soluble sugars by anthrone reaction (Hodge and Hofreiter, 1962).

The residue of the alcoholic extractions was treated with water: $52 \%$ perchloric acid at 1:1.3 and centrifuged three times at $2,000 \times g$ for $10 \mathrm{~min}$, after reaction peri- 
ods of 20,30 and 20 minutes for the three extractions, prior to centrifugation, respectively. The resulting supernatants were combined and completed with distilled water to a volume of $50 \mathrm{~mL}$ and used for starch quantification by the method of McCready et al. (1950), modified by Patel (1970). The PPO and POD activities were determined by the methods described by Silva (1981); Flurkey and Jen (1978), with modifications.

To obtain the enzyme extract, the samples were placed in a test tube with $5 \mathrm{~mL}$ of $0.2 \mathrm{~mol} \mathrm{~L}^{-1}$ phosphate buffer $(\mathrm{pH}=6.0)$, cooled and homogenized in a polytron at $20,500 \mathrm{rpm}$ for $40 \mathrm{~s}$. The suspension was centrifuged at $10,000 \mathrm{xg}$ for $21 \mathrm{~min}$ at $4^{\circ} \mathrm{C}$. After centrifugation, the supernatant or enzyme extract was placed in another test tube in an ice bath.

To determine the PPO activity, $1.3 \mathrm{~mL}$ of $0.2 \mathrm{~mol} \mathrm{~L}^{-1}$ phosphate buffer $\left(\mathrm{pH} 6.0\right.$ ) and $1.5 \mathrm{~mL}$ of $0.2 \mathrm{~mol} \mathrm{~L}^{-1}$ catechol was filled into a test tube. This tube was placed in a thermostatic bath at $25^{\circ} \mathrm{C}$ to stabilize the temperature. Thereafter, $30 \mu \mathrm{L}$ enzyme extract was added, followed by homogenization and then seven absorbance readings were made every $30 \mathrm{~s}$ in a spectrophotometer, at a wavelength of $425 \mathrm{~nm}$. Results were expressed in enzyme units per gram of sample, calculated based on the extract amount that induced an increase in absorbance of 0.001 units per minute.

To determine the POD activity, $2.0 \mathrm{~mL}$ of $0.2 \mathrm{~mol}$ $\mathrm{L}^{-1}$ phosphate buffer ( $\mathrm{pH}$ 6.0) with $0.5 \%$ frozen guaiacol was placed in a test tube. This tube was placed in a thermostatic bath at $30^{\circ} \mathrm{C}$ to stabilize the temperature. After this, $100 \mu \mathrm{L}$ enzyme extract and $100 \mu \mathrm{L}$ of $0.08 \%$ hydrogen peroxide was added, followed by homogenization. Immediately, seven absorbance readings were performed every $30 \mathrm{~s}$ in a spectrophotometer, at $470 \mathrm{~nm}$. The results were expressed in enzyme units per gram of sample, based on the extract amount that induced an increase in absorbance of 0.001 units per minute. All reagents were stored in a refrigerator. The catechol, guaiacol and hydrogen peroxide solutions were prepared and stored in the dark.

Data were submitted to analysis of variance and regression. The linear and nonlinear models were chosen based on the potential to explain the biological phenomenon in question, on the coefficient of determination and significance of the regression coefficients, using the $t$ test at $10 \%$. Descriptive analyses were used for the data of respiration and enzyme activity of PPO and POD.

\section{Results and Discussion}

An increased loss of fresh fruit weight was observed during the evaluations in all treatments. At the end of the evaluations, the fruits damaged by cutting and abrasion had lost $11.2 \%$ and $11.8 \%$ fresh weight, while fruit damaged by impact, compression and the control had lost $9.7 \%, 8.1 \%$ and $8.4 \%$, respectively, nine days after the treatments (Figure 1). There was also intense dehydration in the affected region of the fruits damaged by abrasion and cutting over time. Injury by cutting and abrasion make banana 'Prata Anã' more susceptible to fresh weight loss. Ferris et al. (1993; 1995) and Lladó and Dominguez (1998) also observed that mechanical injuries increased bananas' weight loss.

Although the daily loss of fresh weight tended to be higher in cut and abraded fruits than in fruits of the other treatments, the effect of the type of mechanical damage on daily fresh weight loss was not significant. The daily loss of fresh weight was 1.1, 1.4, 1.4, 1.2, $1.1 \%$ to control, cutting, abrasion, impact and compression, respectively.

An increase in electrolyte leakage over time was detected in fruits of all treatments, as a result of ripening (Figure 2). A trend with three phases was observed in the development of electrolyte leakage from the peel of 'Prata Anã' banana during the evaluation period: in the first phase, the values increased slowly, in the second phase, there was an exponential increase and in the third final phase, a stabilization, that is, a sigmoidal model. Only fruits damaged by abrasion and impact reached the $3^{\text {rd }}$, while the others only reached the $2^{\text {nd }}$ stage. Possibly, if the measurements were continued for a longer period, the control fruits and those damaged by cutting and compression would also reach the last stage. The

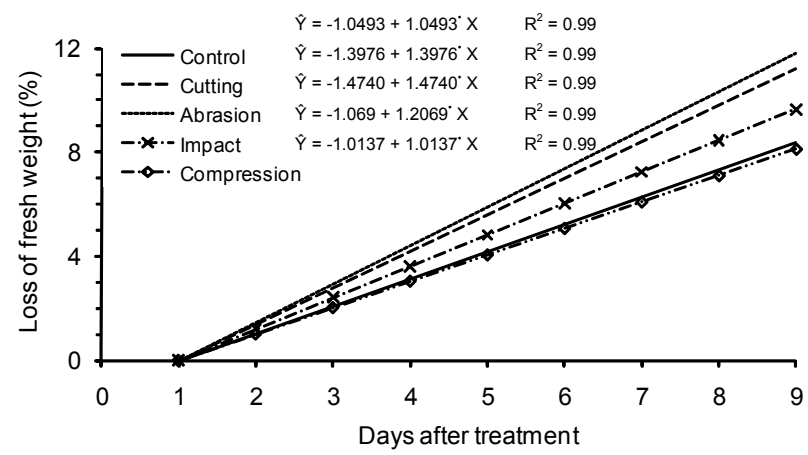

Figure 1 - Loss of accumulated fresh weight of 'Prata Anã' bananas during the storage period at room temperature, as related to types of mechanical damage. $\bullet$ Significant ( test, $p<0.01)$.

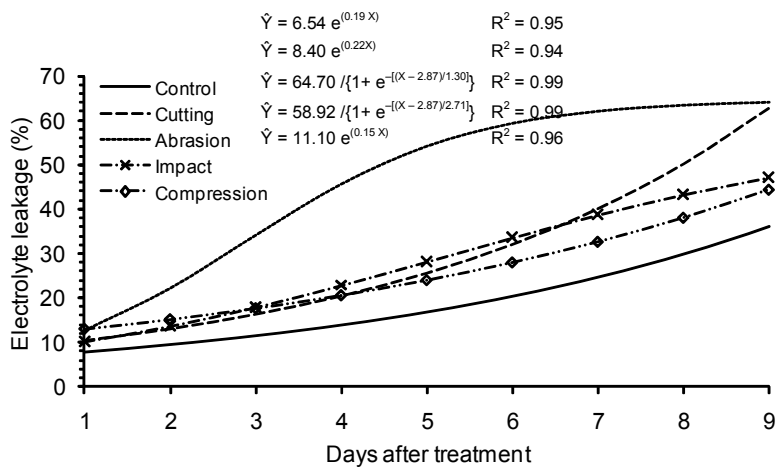

Figure 2 - Electrolyte leakage from the peel of "Prata Anã" bananas during the storage period at room temperature, as related to types of mechanical damage. 
same performance was observed in measurements of total soluble sugars and starch (Figures 3 and 4). Therefore, the traits related to the ripening processes of banana will probably have this type of performance when evaluated over time. Moura et al. (2002) also observed this performance in the carotenoids and lycopene levels of 'Santa Clara' tomato. Likewise, Rocha (2009) observed a similar performance in 'Prata ' banana.

The values of electrolyte leakage in all mechanically damaged were higher than in the control fruits in the evaluation period. The highest electrolyte leakage was found in fruit peel damaged by abrasion, reaching close to maximum values on the $6^{\text {th }}$ day after the treatment. The leakage of total electrolytes from the same fruits was $64.1 \%$ on the last day of evaluation, while fruits damaged by cutting, impact, compression and the control reached values of $62.9 \%, 47.2 \%, 44.5 \%$, and $36.2 \%$, respectively (Figure 2). The reason is that damage by abrasion causes the disruption of a large quantity of epidermis cells. Moreover, the integrity of cell membranes is affected by all types of mechanical damage, since the electrolyte leakage serves as a reference of the membrane integrity or alteration of selective permeability (Fergunson and Watkins, 1981). Furthermore, during the ripening process, the membranes gradually lose the se-

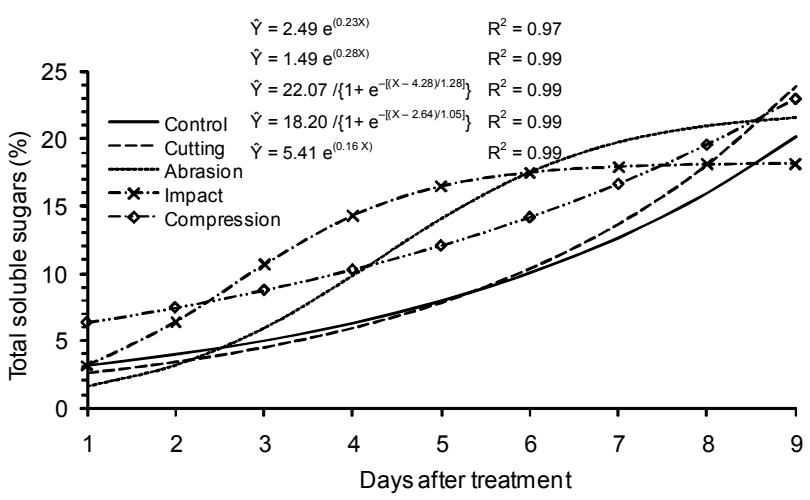

Figure 3 - Total soluble sugars in the pulp of 'Prata Anã' bananas during the storage period at room temperature, as related to types of mechanical damage.

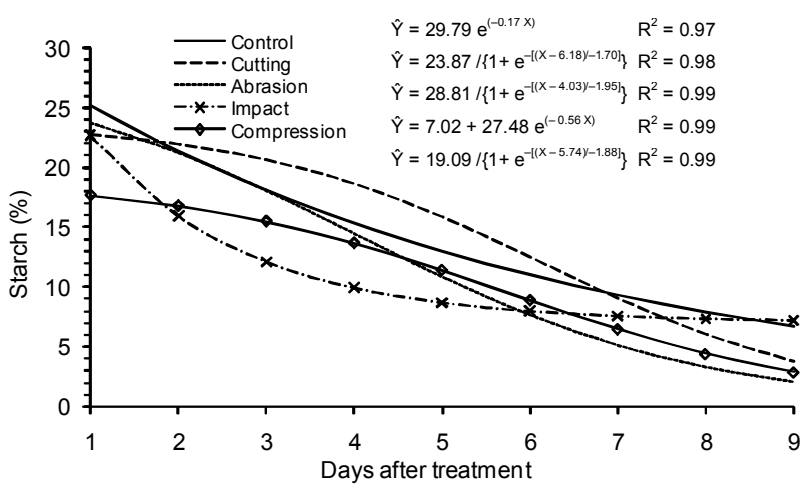

Figure 4 - Starch content of the pulp of 'Prata Anã' bananas during the storage period at room temperature, as related to types of mechanical damage. lective permeability and break (Kays, 1991). Zhou et al. (2007) also observed that mechanical damage affected plasma membrane of pear.

The levels of total soluble sugars in the pulp increased in the fruits of all treatments during the evaluation period (Figure 3) while starch levels decreased (Figure 4). This performance is typical of banana, where fruit ripening is characterized by the conversion of starch to total soluble sugars (Kays, 1991; Wills et al., 1998). The levels of total soluble sugars in fruits injured by cutting, abrasion, impact and compression reached of $23.9 \%$, $21.5 \%, 18.2 \%$, and $23.0 \%$, at the end of the evaluation period, while the control reached $20.1 \%$ (Figure 3). In general, the values of total sugars in the fruit pulp of damaged fruit were higher than in the control fruits during the assessment period. This fact indicates that the mechanically damaged fruits have a higher speed of starch - sugar conversion, i.e., pulp ripening is faster. Mechanical damage stimulates respiratory process and ethylene biosynthesis. The consequence is increased activity of enzymes and starch degradation by $\alpha$-amylase, $\beta$-amylase and glucosidases. The action of these enzymes increases more rapid degradation and the available quantity of sucrose and glucose, which are respiratory substrates leading to higher respiration rate in mechanically damaged fruits (Paliyath et al., 2008; Taiz and Zeiger, 2008).

On the last day of evaluation, the pulp starch content of impact-damaged fruits was $7.2 \%$, whereas the pulp starch levels of fruits damaged by cutting, abrasion, compression and control were $3.8 \%, 2.1 \%, 2.9 \%$, and $6.7 \%$, respectively (Figure 4). Impact injury caused a loss in the starch-sugar conversion in the fruit pulp. At the end of the evaluation period, the total soluble sugar and starch levels in the fruit pulp of this treatment were lowest and highest, respectively, of all treatments. Maia et al. (2003) also observed loss in starch-sugar conversion caused by impact injury. This loss in conversion is confirmed by the stabilization of sugar and starch levels in the pulp from the $6^{\text {th }}$ day of evaluation onwards when reach values close to the maximum and minimum, respectively, (Figures 3 and 4). At the $5^{\text {th }}$ day of evaluation the sugar and starch levels in the pulp of impacted-damage fruits are highest and lowest, respectively, than those injured by cutting, abrasion and compression, or the control fruit.

The peak activity of polyphenoloxidase in the peel of 'Prata Anã' banana was observed on the $7^{\text {th }}$ day after the treatments, when the fruits damaged by impact $\left(1,888.9\right.$ units $\left.\mathrm{g}^{-1}\right)$, abrasion $\left(1,083.3\right.$ units $\left.\mathrm{g}^{-1}\right)$ and cutting (718.3 units $\mathrm{g}^{-1}$ ) also reached higher PPO activity peaks than fruits damaged by compression $\left(579.4\right.$ units $\left.\mathrm{g}^{-1}\right)$ and the control fruits $\left(571.4\right.$ units $\left.\mathrm{g}^{-1}\right)$, showing the fruit response to these injuries (Figure 5). These results indicate an increase of up to $25.7 \%, 89.6 \%$ and $230.6 \%$ in the enzyme activity of fruits damaged by cutting, abrasion and impact, compared to the control. Therefore, impact and abrasion, particularly impact damage, resulted in a substantial increase in PPO activity, compared to the other treatments. This confirms that the increased PPO activity is directly related to cell disruption. 
In response to the stress of the mechanical damage treatments, which expose the plant tissue to several injuries, phenols are produced and hydrogen peroxide is released (Buchanan et al., 2000; Taiz and Zeiger, 2008). The oxidative enzymes are activated by a breakdown of the cell membranes (Ferrer et al., 1989), and act in the oxidation of phenolic compounds (Siddiq et al., 1992) and lignin biosynthesis (Lagrimini, 1991). The darkening observed in the affected region of the peel due to cell collapse, confirmed by the leakage of electrolytes, leads to a mixture of enzymes and substrates that result in the enzymatic oxidation of colorless substrates which, in the presence of oxygen, are converted to dark-colored products (Ju and Zhu, 1988; Acican et al., 2007).

The peroxidase activity in the peel of 'Prata Anã' banana was comparable to the polyphenoloxidase activity over time and according to the treatments. Similarly, the peroxidases, which are membrane proteins, are activated by mechanical disruption (Reimmann et al., 1992). Analogously to PPO, POD activity reached a peak in the fruits damaged by abrasion $\left(12.515 .3\right.$ units $\left.\mathrm{g}^{-1}\right)$, impact $\left(8,509.5\right.$ units $\left.\mathrm{g}^{-1}\right)$ and compression $\left(1,726.3\right.$ units $\left.\mathrm{g}^{-1}\right)$ on the $7^{\text {th }}$ day after the treatment and in the control fruits $\left(1,184.5\right.$ units $\left.\mathrm{g}^{-1}\right)$ on the $5^{\text {th }}$ day after the treatment, although in this case the peak was less evident.

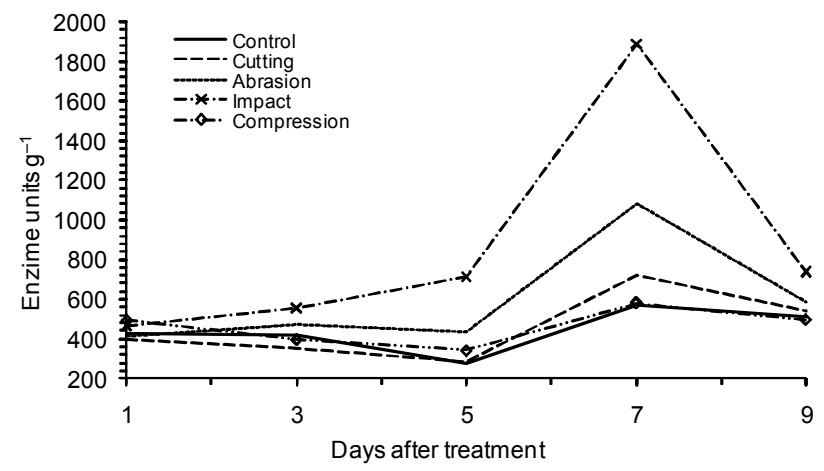

Figure 5 - Polyphenoloxidase activity in peel of 'Prata Anã' bananas during the storage period at room temperature, as related to types of mechanical damage.

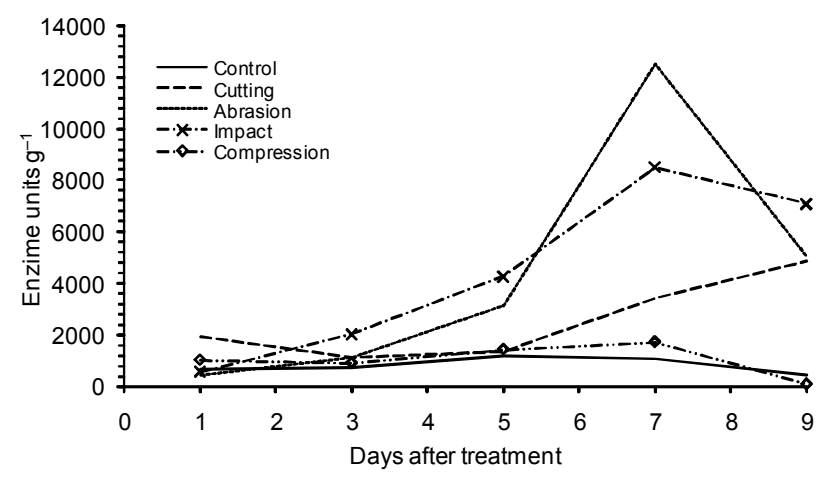

Figure 6 - Peroxidase activity in peel of 'Prata Anã' bananas during the storage period at room temperature, as related to types of mechanical damage
Regarding the damage by cutting, no POD peak activity was observed, but rather an increasing activity of this enzyme until the last day of evaluation $(4,860.7$ units $\mathrm{g}^{-1}$ ) (Figure 6). Moreover, the POD activity of fruits affected by impact, abrasion and cutting was higher than in control and compression-damaged fruits (Figure 6). At the POD activity peak, the values reached increases of up to $310.4 \%, 956.6 \%$ and $618.4 \%$ in fruits damaged by cutting, abrasion and impact, in comparison with the control. Therefore, abrasion and impact, particularly abrasion damage, led to a substantial increase in POD activity, compared to the other treatments.

The results of increased PPO and POD activity confirm the stress of damaged fruits, particularly by cutting, abrasion and impact injuries. The browning of the damaged region due to oxidative enzyme activity results in an unpleasant appearance for the consumer and the taste, flavor, color and texture may be altered (Paliyath et al., 2008). Similar results were found by Acican et al. (2007), Cantos et al. (2002) and Zhou et al. (2007). On discriminating markets, fruits with these symptoms are often rejected and thrown away, contributing to the waste of food.

The most important factors that determine the rate and intensity of enzymatic browning are the activity of enzyme, concentration of the specific polyphenols present in the tissue, oxygen availability, the $\mathrm{pH}$, and the temperature (Martinez and Whitaker, 1995). Browning reactions are also dependent on the mechanical integrity of cell membranes according to the results observed. In general, compression damage caused no harmful effect to the bananas. Fruits with peel color grade 1 are most likely tolerant to this type of mechanical damage.

\section{Conclusions}

Damage by cutting and abrasion increased fruit weight loss and electrolyte leakage. Impact damage accelerated the ripening of 'Prata Anã' bananas, besides affecting the conversion of starch to total soluble sugars in the pulp. "Prata Anã" bananas with peel color grade 1 were tolerant to compression damage.

\section{Acknowledgements}

To the Conselho Nacional de Desenvolvimento Científico e Tecnológico (CNPq), Fundação de Amparo a Pesquisa do Estado de Minas Gerais (FAPEMIG), and Agropecuária Veloso Maia.

\section{References}

Acican, T.; Alibas, K.; Özelkök, I.S. 2007. Mechanical damage to apples during transport in wooden crates. Biosystems Engineering 96: 239-248.

Buchanan, B.B.; Gruissen, W.; Jones, R.L. 2000. Biochemistry and Molecular Biology of Plants. American Society of Plant Physiologists, Rockville, MD, USA. 
Cantos, E.; Tudela, J.A.; Gil, M.I.; Espin, J.C. 2002. Phenolic compounds and related enzymes are not ratelimiting in browning development of fresh-cut potatoes. Journal of Agricultural and Food Chemistry 50: 3015-3023.

Dadzie, B.K.; Orchard, J.E. 1997. Routine Post-Harvest Screening of Banana/Plantain Hybrids: Criteria and Methods. International Network for the Improvement of Banana and Plantains, Montpellier, France. 63 p. (INIBAP Technical Guidelines, 2).

Ferrer, A.S.; Bru, R.; Garcia-Carmona, F. 1989. Novel procedure for extraction of a latent grape polyphenoloxidase using temperature-induced phase separation in Triton X-114. Plant Physiology 91: 1481-1487.

Fergunson, I.B.; Watkins, C.B. 1981. Ion relation of apple tissue during fruit development and ripening. I. Cation leakage. Australian Journal of Plant Physiology 8: 155-164.

Fischer, I.H.; Ferreira, M.D.; Spósito, M.B.; Amorim, L. 2009. Citrus postharvest diseases and injuries related to impact on packing lines. Scientia Agricola 66: 210-217.

Flurkey, W.H.; Jen, J.J. 1978. Peroxidase and polyphenol oxidase activities in developing peaches. Journal of Food Science 43: 1826-1831.

Hodge, J.E.; Hofreiter, B.T. 1962. Determination of reducing sugars and carbohydrates. p. 380-394. In: Whistler, R.L.; Wolfrom, M.L., eds. Methods in carbohydrate chemistry. Academic Press, New York, NY, USA.

Ju, Z.G.; Zhu, G.L. 1988. Research on tissue browning of fruit during storage. Plant Physiology Communications 4: 46-48.

Kays, S.J. 1991. Postharvest physiology of perishable plant products. AVI, New York, NY, USA.

Lagrimini, L.M. 1991. Wound-induced deposition of polyphenol in transgenic plants overexpressing peroxidase. Plant Physiology 96: 577-583.

Maia, V.M.; Salomão, L.C.C.; Cantarutti, R.B.; Venegas, V.H.A 2003. Effect of nitrogen, phosphorus and potassium fertilization on accumulation of macronutrients and susceptibility of 'Prata Anã' banana to mechanical damage. Revista Ceres 50: 753-765. (in Portuguese, with abstract in English).

Maia, V.M.; Salomão, L.C.C.; Siqueira, D.L.; Puschmann, R.; Mota Filho, V.J.G.; Cecon, P.R. 2007. Types and intensity of mechanical damages on 'prata anã' bananas along the commercialization chain. Revista Brasileira de Fruticultura 30: 365-370. (in Portuguese, with abstract in English).
Martinez, M.V.; Whitaker, J.R. 1995. The biochemistry and control of enzymatic browning. Trends in Food Science \& Technology. 6: $195-200$.

McCready, R.M.; Guggolz, J.; Silveira, V.; Owens, H.S. 1950. Determination of starch and amylose in vegetables. Application to peas. Analytical Chemistry 22: 1156-1158.

Moura, M.L.; Moura, M.A.; Pinto, C.M.F.; Finger, F.L. 2002. Physiology of vine-ripened tomato 'Santa Clara' and its mutant 'Firme'. Revista Brasileira de Armazenamento 27: 3-8. (in Portuguese, with abstract in English).

Paliyath, G.; Murr, D.P.; Handa, A.K.; Lurie, S. 2008. Postharvest Biology and Technology of Fruits, Vegetables, and Flowers. Wiley-Blackwell, Ames, IA, USA.

Reimmann, C.R.; Ringli, C.; Dudle, R. 1992. Complementary DNA cloning and sequence analysis of a pathogen-induced putative peroxidase from rice. Plant Physiology 100: 1611-1612.

Rocha, A.; Salomão, L.C.C.; Bruckner, C.H.; Cecon, P.R. 2009. Potassium permanganate use in postharvest of 'Prata' banana stored under refrigeration. Revista Brasileira de Armazenamento 34: 40-48. (in Portuguese, with abstract in English).

Siddiq, M.; Sinha, N.K.; Cash, J.N. 1992. Characterization of polyphenoloxidase from Stanley plums. Journal of Horticultural Science 70: 263-269.

Taiz, L.; Zeiger, E. 2008. Fisiologia Vegetal. Artmed, Porto Alegre, RS, Brazil.

Wills, R.; McGlasson, B.; Graham, D.; Joyce, D. 1998. Postharvest: An Introduction to the Physiology and Handling of Fruits, Vegetables and Ornamentals. CABI, Wallingford, UK.

Whilton, T.H.; Bassuk, N.L.; Ranney, T.G.; Reichert, D.L. 1992. An improved method for using electrolyte leakage to access membrane competence in plant tissues. Plant Physiology 98: 198-205.

Zeebroeck, M.V.; Linden, V.V.; Ramon, H.; Baerdemaeker, J.D.; Nicolaï, B.M.; Tijskens, E. 2007. Impact damage of apples during transport and handling. Postharvest Biology and Technology 45: 157-167.

Zhou, R.; Su, S.; Yan, L.; Li, Y. 2007. Effect of transport vibration levels on mechanical damage and physiological responses of Huanghua pears (Pyrus pyrifolia Nakai, cv. Huanghua). Postharvest Biology and Technology 46: 20-28.

Received August 08, 2009

Accepted May 19, 2010 